\title{
Krzysztof Gawron
}

Uniwersytet Marii Curie-Skłodowskiej w Lublinie e-mail: krzysztof.gawron@poczta.umcs.lublin.pl

\section{PREZENTACJA KOSZTÓW POSTĘPOWANIA UPADLOŚCIOWEGO W SPRAWOZDANIU FINANSOWYM PRZEDSIĘBIORSTWA W UPADLOŚCI LIKWIDACYJNEJ}

\section{PRESENTATION OF COSTS OF BANKRUPTCY PROCEEDINGS IN THE FINANCIAL STATEMENT OF AN ENTERPRISE IN BANKRUPTCY LIQUIDATION PROCEEDINGS}

\section{DOI: $10.15611 /$ pn.2018.524.04}

JEL Classification: G33, M41

Streszczenie: Rolą syndyka w postępowaniu upadłościowym zmierzającym do likwidacji majątku dłużnika jest sprawne i efektywne działanie w celu zaspokojenia wierzycieli w jak największym stopniu. Czynności syndyka podlegają kontroli sądu, wierzycieli oraz innych interesariuszy. Podstawową kategorią ekonomiczną wpływającą na efektywność postępowania są koszty upadłości. Sprawozdanie finansowe podmiotu postępowania upadłościowego powinno je zatem jednoznacznie identyfikować i prezentować. Celem artykułu jest propozycja modyfikacji sprawozdania finansowego, tak aby jednoznacznie ujawniało ono informacje o poniesionych i przewidywanych kosztach postępowania upadłościowego. Zastosowaną metodą badawczą jest analiza literatury przedmiotu i regulacji prawnych. W artykule scharakteryzowano pojęcie kosztów upadłości oraz zaprezentowano możliwości ujawniania $\mathrm{z}$ większą szczegółowością informacji o tych kosztach w bilansie, rachunku zysków i strat oraz informacji dodatkowej sporządzanych zgodnie z regulacjami polskiego prawa bilansowego.

Słowa kluczowe: koszty upadłości, sprawozdanie finansowe, postępowanie upadłościowe.

Summary: The role of the administrative receiver in bankruptcy liquidation proceedings is the efficient and effective implementation of procedures to satisfy creditors' claims as far as possible. The receiver's activities are controlled by the court, creditors and other stakeholders. One of the most important economic categories affecting the efficiency of the proceedings are the costs of bankruptcy. The financial statements of the bankruptcy proceedings entity should therefore identify and present them. The purpose of the article is to propose a modification of the financial statements, so that it clearly discloses information about the incurred and expected costs of bankruptcy proceedings. The research method used in the study is the analysis of the literature and legal regulations. The article describes the concept of bankruptcy costs and 
presents detailed possibilities of disclosing information about these costs in the balance sheet, profit and loss account and additional information prepared in accordance with the regulations of Polish balance sheet law.

Keywords: costs of bankruptcy, financial statements, bankruptcy proceedings.

\section{Wstęp}

Upadłość stanowi instytucję prawną wspólnego dochodzenia roszczeń wierzycieli od niewypłacalnych dłużników. Postępowanie upadłościowe powinno być prowadzone tak, aby roszczenia wierzycieli mogły zostać zaspokojone w jak najwyższym stopniu, a przedsiębiorstwo dłużnika - o ile jest to racjonalne ekonomicznie - zostało zachowane [Ustawa z 28 lutego 2003, art. 1, 2]. Podstawowe cele instytucji upadłości to:

- naprawa szkody poniesionej na skutek niewypłacalności dłużnika przez sprawnie działające jednostki gospodarcze,

- eliminacja z obrotu gospodarczego jednostek nierentownych,

- zapewnienie maksymalnego poziomu spłaty wierzytelności w toku procedur upadłościowych,

- minimalizacja kosztów postępowania upadłościowego i czasu jego prowadzenia,

- dążenie do utrzymania działalności przedsiębiorstwa dłużnika, jego restrukturyzacja ${ }^{1} \mathrm{w}$ celu przywrócenia mu zdolności do generowania zysków [Babiarz-Mikulska $\mathrm{i}$ in. 2012, s. 69].

W sytuacji gdy nie jest możliwa restrukturyzacja niewypłacalnego przedsiębiorstwa, sąd ogłasza decyzję o przeprowadzeniu postępowania upadłościowego zmierzającego do likwidacji majątku dłużnika. Upadłość likwidacyjna wymusza pozyskanie funduszy na spłatę wierzytelności poprzez sprzedaż jednostki, jej zorganizowanej części lub poszczególnych składników mienia wchodzących w skład tzw. masy upadłości. Sędzia prowadzący postępowanie, zwany sędzią-komisarzem, wyznacza syndyka do prowadzenia jednostki upadłej. Zadaniem nowego kierownika jednostki jest ustalenie składu i oszacowanie wartości majątku stanowiącego masę upadłości. Mienie to będzie sprzedawane według sposobów i terminów wskazanych w przyjętym i zatwierdzonym przez sąd planie likwidacyjnym. Równolegle sporządzana jest lista wierzytelności, a roszczenia wierzycieli są dzielone na kategorie interesu. Po zatwierdzeniu planów podziału następuje faktyczna likwidacja majątku, czyli jego sprzedaż w drodze przetargu lub z wolnej ręki. Sumy uzyskane z likwidacji masy upadłości oraz dochód z prowadzenia lub wydzierżawienia przedsiębiorstwa upadłego, powiększone o odsetki od środków pieniężnych zdeponowa-

1 Od 1 stycznia 2016 r. postępowania restrukturyzacyjne, w tym upadłość układowa, zostały wyłączone z regulacji prawa upadłościowego i są realizowane zgodnie z przepisami ustawy Prawo restrukturyzacyjne [Ustawa z 15 maja 2015]. 
nych w banku tworzą fundusze masy upadłości [Ustawa z 28 lutego 2003, art. 335]. Fundusze masy upadłości, pomniejszone o koszty postępowania upadłościowego, są dzielone między wierzycieli zgodnie z przyjętym planem podziału. Po spieniężeniu całości masy upadłości i zrealizowaniu planów podziału następuje zakończenie postępowania w upadłości likwidacyjnej.

Rolą syndyka jest sprawne i efektywne podejmowanie działań w celu zaspokojenia wierzycieli w jak największym stopniu. Jego czynności podlegają kontroli ze strony sądu, wierzycieli oraz innych interesariuszy. Informacje niezbędne do sprawowania tej kontroli są przekazywane przez syndyka w ramach realizacji jego obowiązków sprawozdawczych. Są nimi:

- wynikające z ustawy o rachunkowości sprawozdania finansowe sporządzane na dzień poprzedzający ogłoszenie upadłości, na koniec każdego roku obrotowego w trakcie trwania procedur upadłościowych oraz na dzień ich zakończenia,

- wynikające z przepisów prawa upadłościowego, przekazywane do sądu, sprawozdania okresowe $\mathrm{z}$ czynności dokonanych w toku postępowania upadłościowego oraz tzw. sprawozdania rachunkowe,

- wynikające z innych uregulowań prawnych sprawozdania i raporty, w tym głównie sprawozdania o charakterze statystycznym oraz deklaracje podatkowe [Popławska (red.) 2004].

$\mathrm{Z}$ uwagi na fakt, że realizacja procedur upadłościowych generuje koszty upadłości, których wartość bezpośrednio wpływa na efektywność postępowania, powinny być one jednoznacznie zidentyfikowane i zaprezentowane w sprawozdaniach syndyka. Celem artykułu jest przedstawienie propozycji modyfikacji sprawozdania finansowego, tak aby jednoznacznie ujawniało ono informacje o poniesionych i przewidywanych w trakcie postępowania kosztach upadłości. W dalszej części opracowania zostaną zaprezentowane możliwości uszczegółowienia bilansu, rachunku zysków i strat oraz informacji dodatkowej o powyższe dane.

\section{Charakterystyka kosztów postępowania upadłościowego}

Rachunkowość podmiotów objętych procedurami upadłościowymi prowadzona jest zgodnie z regulacjami polskiego prawa bilansowego, dlatego definicja kosztów postępowania powinna bazować na zapisach ustawy o rachunkowości. Koszty te można zatem zdefiniować jako uprawdopodobnione w trakcie likwidacji majątku zmniejszenie korzyści ekonomicznych, w wiarygodnej wartości, zmniejszające aktywa albo zwiększające zobowiązania i rezerwy, w końcowym efekcie zmniejszające kapitał podstawowy [Piotrowska 2014, s. 418].

Koszty postępowania upadłościowego stanowią element szerszego pojęcia, jakim są koszty bankructwa, nazywane w literaturze często po prostu kosztami upadłości. Obejmują one koszty poprzedzające proces upadłości (zarówno koszty bezpośrednie, związane z wystąpieniem trudnej sytuacji finansowej, oraz trudno mierzalne koszty pośrednie upadłości (zob. szerzej [Chłodnicka 2004; Chłodnicka, 
Zimon 2013, s. 68]), jak i koszty postępowania upadłościowego, w tym koszty postępowania sądowego, koszty administracyjne syndyka oraz koszty likwidacyjne) [Tokarski 2012, s. 623], a niekiedy również koszty powstałe po zakończeniu procedur upadłościowych [Boratyńska 2009, s. 182].

Polskie prawo upadłościowe, zarówno w wersji funkcjonującej do początku 2016 r. w postaci ustawy Prawo upadłościowe i naprawcze, jak i jej obecnie obowiązująca znowelizowana wersja, tj. Prawo upadłościowe, zawiera wykaz elementów zaliczanych do kosztów postępowania upadłościowego. Zestawienie tych składników prezentuje tabela 1 .

Tabela 1. Koszty postępowania upadłościowego według polskiego prawa upadłościowego

\begin{tabular}{|c|c|}
\hline \multicolumn{2}{|c|}{ Koszty postępowania upadłościowego } \\
\hline Według ustawy Prawo upadłościowe & Według ustawy Prawo upadłościowe i naprawcze \\
\hline $\begin{array}{l}\text { 1. Wydatki bezpośrednio związane } \\
\text { z zabezpieczeniem, zarządem i likwidacją masy } \\
\text { upadłości. } \\
\text { - } \quad \text { Wynagrodzenie syndyka i jego zastępcy. } \\
\text { - Wynagrodzenia osób zatrudnionych przez } \\
\text { syndyka. } \\
\text { - Należności z tytułu składek na ubezpieczenia } \\
\text { społeczne od wynagrodzeń tych osób. } \\
\text { - Wynagrodzenie i wydatki członków rady } \\
\text { - wierzycieli. } \\
\text { - Wydatki związane ze zgromadzeniem } \\
\text { wierzycieli. } \\
\text { - Koszty archiwizacji dokumentów upadłego. } \\
\text { - } \quad \text { Poszty korespondencji i ogłoszeń. } \\
\text { z likwidacją masy upadłości. } \\
\text { 2. Inne zobowiązania masy upadłości powstałe po } \\
\text { ogłoszeniu upadłości: } \\
\text { - Należności ze stosunku pracy przypadające za } \\
\text { czas po ogłoszeniu upadłości. } \\
\text { - Zobowiązania z tytułu bezpodstawnego } \\
\text { wzbogacenia masy. } \\
\text { - Zobowiązania z tytułu zawartych przez upadłego } \\
\text { umów, których wykonania zażądał syndyk. } \\
\text { Inne zobowiązania powstałe z czynności } \\
\text { syndyka. } \\
\text { Przypadające za czas po ogłoszeniu upadłości } \\
\text { renty z tytułu odszkodowania za wywołanie } \\
\text { choroby, niezdolności do pracy, kalectwa lub } \\
\text { śmierci i renty z tytułu zmiany uprawnień } \\
\text { objętych treścią prawa dożywocia na dożywotnią } \\
\text { rentę. }\end{array}$ & $\begin{array}{l}\text { 1. Opłaty sądowe. } \\
\text { 2. Wydatki niezbędne do osiągnięcia celu } \\
\text { postępowania: } \\
\text { - Wynagrodzenie i wydatki syndyka, nadzorcy } \\
\text { - } \quad \text { Wądowego i zarządcy oraz ich zastępców. } \\
\text { wierzycieli oraz wydatki związane ze } \\
\text { zgromadzeniem wierzycieli. } \\
\text { - Należności z tytułu składek na ubezpieczenia } \\
\text { społeczne od powyższych wynagrodzeń. } \\
\text { - Koszty obwieszczeń i ogłoszeń. } \\
\text { - Koszty postępowania dowodowego oraz } \\
\text { wysłuchania. } \\
\text { - Koszty zgromadzenia wierzycieli, wydatki } \\
\text { poniesione przez radę wierzycieli oraz } \\
\text { wynagrodzenia członków rady wierzycieli } \\
\text { 3. Wydatki postępowania likwidacyjnego: } \\
\text { - Koszty likwidacji masy upadłości. } \\
\text { - Wynagrodzenia pracowników zatrudnionych } \\
\text { w przedsiębiorstwie upadłego należne za } \\
\text { okres po ogłoszeniu upadłości oraz odprawy } \\
\text { i odszkodowania związane z rozwiązaniem } \\
\text { umów o pracę, przysługujące tym pracownikom. } \\
\text { - Należności z tytułu składek na ubezpieczenie } \\
\text { emerytalne, rentowe i chorobowe od } \\
\text { - } \text { wynagrodzeń powyższych osób. } \\
\text { podatki i inne daniny publiczne należne za okres } \\
\text { - Kogłoszeniu upadłości. } \\
\text { przez syndyka po ogłoszeniu upadłości. }\end{array}$ \\
\hline
\end{tabular}

Źródło: opracowanie własne na podstawie [Ustawa z 28 lutego 2003, Dz.U. z 2003, nr 60, poz. 535, art. 230; Ustawa z 28 lutego 2003, Dz.U. z 2017, poz. 2344, art. 230]. 
Zaprezentowane w tabeli 1 składniki kosztów postępowania upadłościowego, wymienione w polskim prawie upadłościowym, zawierają pojęcia takie, jak wydatki, należności i zobowiązania, które na gruncie rachunkowym nie są tożsame z kategorią kosztu. Uzasadnione jest doprecyzowanie definicji zawartych w prawie upadłościowym regulacji i ich zharmonizowanie z przepisami ustawy o rachunkowości.

\section{Sprawozdanie finansowe przedsiębiorstwa w upadłości likwidacyjnej}

Sprawozdanie finansowe stanowi końcowy efekt rachunkowości finansowej, za pomocą którego jednostka gospodarcza komunikuje swojemu otoczeniu informacje o prowadzonej działalności. Z uwagi na fakt, że rachunkowość dostarcza ogromnej ilości danych o różnej wartości poznawczej i różnym stopniu uogólnienia, konieczna jest ich właściwa selekcja i pogrupowanie w postaci sprawozdań dostosowanych do potrzeb ich odbiorców [Świderska, Więcław (red.) 2012, s. 40].

Jednostki gospodarcze objęte postępowaniem upadłościowym muszą sporządzać sprawozdanie finansowe na dzień poprzedzający ogłoszenie upadłości, na koniec każdego roku obrotowego w czasie trwania procedur upadłościowych oraz na dzień ich zakończenia. Sporządzenie rocznego sprawozdania finansowego powinno nastąpić nie później niż w ciągu 3 miesięcy od dnia bilansowego. Sprawozdanie finansowe powinno zawierać podpisy wraz z datą złożenia podpisu osoby odpowiedzialnej za prowadzenie ksiąg rachunkowych oraz kierownika jednostki, tj. syndyka [Ustawa z 29 września 1994, art. 52].

Roczne sprawozdanie finansowe jednostki gospodarczej objętej postępowaniem upadłościowym nie podlega obowiązkowi badania przez biegłego rewidenta. Decyzja o dobrowolnym poddaniu się badaniu należy do kompetencji kierownika jednostki. Sprawozdanie podmiotu postępowania upadłościowego nie podlega również zatwierdzeniu. W ciągu sześciu miesięcy od dnia bilansowego powinno zostać złożone w rejestrze sądowym, w ciągu 15 dni od daty upływu tego terminu [Ustawa z 29 września 1994, art. 53]. Podmioty postępowania upadłościowego powinny także przedstawić to sprawozdanie sędziemu-komisarzowi, który dołącza je do akt sprawy. Sprawozdania finansowe podmiotów w stanie upadłości nie są ogłaszane.

Polska ustawa o rachunkowości zawiera wzory poszczególnych elementów sprawozdania finansowego sporządzanych przez różne podmioty. Wzory te mogą jednak być według potrzeb uszczegóławiane. Podawanie informacji z większą szczegółowością niż wskazana w ustawie o rachunkowości może wynikać ze specyfiki jednostki lub konkretnych potrzeb informacyjnych użytkowników tych sprawozdań.

Roczne sprawozdanie finansowe zgodnie $\mathrm{z}$ polskim prawem bilansowym w przypadku jednostek, które nie są zobowiązane do ich publikowania, składa się z: wprowadzenia do sprawozdania finansowego, bilansu, rachunku zysków i strat oraz dodatkowych informacji i objaśnień. 


\subsection{Prezentacja kosztów postępowania upadłościowego w bilansie}

Układ bilansu, zarówno po stronie aktywów, jak i pasywów, służy ocenie sytuacji majątkowej, płynności i wypłacalności. W przypadku przedsiębiorstw, co do których sąd ogłosił upadłość, tego typu analizy są nie tylko zupełnie niemiarodajne ze względu na nieporównywalność danych, ale także niepotrzebne. W sytuacji, jaką jest stan upadłości, nadrzędnym celem sporządzania sprawozdania finansowego staje się odpowiedź na pytanie, w jakim stopniu majątek dłużnika zaspokoi wierzycieli. Dlatego bilans powinien przede wszystkim służyć właściwemu oszacowaniu majątku masy upadłości. Realna ocena stopnia zaspokojenia roszczeń wierzycieli jednak wymaga dodatkowo informacji na temat spodziewanych kosztów postępowania. To one w pierwszej kolejności podlegają spłacie ze zgromadzonych w trakcie realizacji procedur upadłościowych funduszy. Koszty postępowania upadłościowego podlegają oszacowaniu w ciągu pierwszego miesiąca od decyzji sądu o upadłości i są wykazywane w przekazywanym sędziemu-komisarzowi, wraz z planem prowadzenia upadłości, preliminarzu wydatków. Oszacowanie to jest podstawą utworzenia rezerw na koszty postępowania, które są wykazywane w bilansie. Mogą być one zaprezentowane w sposób pokazany w tabeli 2 .

Tabela 2. Prezentacja rezerw na koszty postępowania upadłościowego w bilansie przedsiębiorstwa

\begin{tabular}{|l|l|l|}
\hline \multicolumn{1}{|c|}{ Pasywa } & \multicolumn{2}{c|}{ Stan na } \\
\cline { 2 - 3 } & $\ldots \ldots$ & $\ldots \ldots$ \\
\hline A. Kapitał (fundusz) własny & & \\
\hline$\ldots .$. & & \\
\hline B. Zobowiązania i rezerwy na zobowiązania & & \\
\hline I. Rezerwy na zobowiązania & & \\
\hline ..... & & \\
\hline $\begin{array}{l}\text { 3. Rezerwa na przewidywane dodatkowe koszty i straty spowodowane } \\
\text { zaniechaniem lub utratą zdolności do kontynuowania działalności }\end{array}$ & & \\
\hline a) koszty osobowe & & \\
\hline b) koszty i kary związane z zerwaniem kontraktów & & \\
\hline c) koszty wyceny majątku i sporządzania sprawozdania & & \\
\hline d) archiwizacja dokumentacji & & \\
\hline e) koszty administracyjne & & \\
\hline f) koszty sądowe & & \\
\hline g) pozostałe koszty upadłości & & \\
\hline 4. Pozostałe rezerwy & & \\
\hline
\end{tabular}

Źródło: opracowanie własne. 
Łączna informacja na temat wartości masy upadłości, przewidywanych kosztów postępowania oraz zgłoszonych wierzytelności podlegających zaspokojeniu w ramach poszczególnych kategorii interesu znacząco upraszcza i pozwala obiektywnie ocenić wierzycielom, w jakim stopniu ich roszczenia zostaną w toku postępowania zaspokojone.

\subsection{Prezentacja kosztów postępowania upadłościowego w rachunku zysków i strat}

Rachunek zysków i strat ma na celu dostarczyć informacji o wygospodarowanym wyniku finansowym i elementach, które się na niego złożyły. Tymi elementami składowymi są uzyskane w danym okresie przychody i poniesione koszty związane z podstawową działalnością operacyjną, pozostałą działalnością operacyjną, działalnością finansową oraz obciążenia podatkowe. Układ rachunku zysków i strat powinien zapewniać możliwość dokonania analizy rentowności podmiotu. Jednostki w stanie upadłości z definicji są nierentowne. Zadaniem rachunku zysków i strat jest zatem ukazanie elementów składowych generowanego w danym okresie wyniku, ze szczególnym uwzględnieniem przychodów i kosztów tworzonych w związku z realizacją procedur upadłościowych. Należy zatem odrębnie wykazać skutki wynikowe działalności kontynuowanej od wyników generowanych w ramach realizacji procedur upadłościowych. Takie rozwiązanie prezentuje tabela 3.

Tabela 3. Formularz rachunku zysków i strat jednostki gospodarczej objętej postępowaniem upadłościowym

\begin{tabular}{|l|c|c|c|c|c|c|}
\hline \multirow{2}{*}{ Rachunek zysków i strat } & \multicolumn{2}{|c|}{$\begin{array}{c}\text { Działalność } \\
\text { kontynuowana }\end{array}$} & \multicolumn{2}{|c|}{$\begin{array}{c}\text { Realizacja procedur } \\
\text { upadłościowych }\end{array}$} & \multicolumn{2}{c|}{ Razem } \\
\cline { 2 - 7 } & $\ldots \ldots .$. & $\ldots \ldots$ & $\ldots \ldots$ & $\ldots \ldots$ & $\ldots \ldots$ & $\ldots \ldots \ldots$ \\
\hline & & & & & & \\
\hline & & & & & & \\
\hline
\end{tabular}

Źródło: opracowanie własne.

Zaletą powyższego rozwiązania jest możliwość oddzielnego ujawnienia przychodów i kosztów upadłości według przyjętych w rachunkowości sfer działalności podmiotu, tj. dotyczących podstawowej działalności operacyjnej, pozostałej działalności operacyjnej oraz działalności finansowej. Ułatwia to analizę wpływu poszczególnych grup przychodów i kosztów na ostateczną wartość wyniku. Przedstawiony układ rachunku zysków i strat jest uniwersalny, co umożliwia jego wykorzystanie zarówno w przypadku upadłości likwidacyjnej², jak i w postępowaniach restruktu-

${ }^{2}$ Decyzją sędziego-komisarza podmiot postępowania likwidacyjnego może kontynuować działalność statutową w trakcie procedur upadłościowych, jeśli istnieją uzasadnione przesłanki, że możliwa 
ryzacyjnych. Informacja na temat wartości i struktury kosztów postępowania upadłościowego jest jedną z najważniejszych z punktu widzenia potrzeb wierzycieli oraz innych użytkowników sprawozdania. Dlatego niezbędne jest uszczegółowienie danych w tym zakresie. Zestawienie poszczególnych pozycji kosztów upadłości poniesionych w okresie sprawozdawczym powinno zostać przedstawione $\mathrm{w}$ informacji dodatkowej.

\subsection{Prezentacja kosztów postępowania upadłościowego w informacji dodatkowej}

Informacja dodatkowa stanowi element sprawozdania finansowego, który służy do poprawnego zrozumienia treści pozostałych elementów sprawozdania. Obejmuje ona dwie części: wprowadzenie do sprawozdania finansowego oraz dodatkowe informacje i objaśnienia. Najistotniejsze elementy wprowadzenia do sprawozdania finansowego sporządzanego przez jednostkę gospodarczą będącą podmiotem postępowania upadłościowego to:

1. Informacje o jednostce sporządzającej sprawozdanie:

- dane identyfikacyjne,

- przedmiot działalności,

- przyczyny upadłości,

- data postanowienia o ogłoszeniu upadłości,

- plan prowadzenia upadłości.

2. Wskazanie okresu objętego sprawozdaniem.

3. Określenie, czy sprawozdanie zostało sporządzone przy założeniu kontynuacji działania.

4. Omówienie przyjętych zasad polityki rachunkowości ze wskazaniem zmian dokonanych $\mathrm{w}$ polityce rachunkowości $\mathrm{w}$ związku $\mathrm{z}$ ogłoszeniem upadłości oraz opisem skutków tych zmian w stosunku do roku poprzedniego.

Dodatkowe informacje i objaśnienia zawierają szczegółowy opis pozycji przedstawionych syntetycznie w bilansie i rachunku zysków i strat. Z punktu widzenia ujawnień dotyczących kosztów postępowania upadłościowego najistotniejsze są dane uzupełniające na temat pozycji rachunku zysków i strat. Klasyfikacja tych kosztów, dostosowana do przedstawionej w opracowaniu propozycji rachunku zysków i strat dla jednostki objętej postępowaniem upadłościowym zmierzającym do likwidacji masy upadłości, została przedstawiona w tabeli 4.

będzie sprzedaż działającego przedsiębiorstwa w całości. 
Tabela 4. Klasyfikacja kosztów postępowania upadłościowego jednostek objętych postępowaniem zmierzającym do likwidacji masy upadłości

\begin{tabular}{|c|c|c|}
\hline \multicolumn{3}{|c|}{ Koszty postępowania upadłościowego } \\
\hline $\begin{array}{c}\text { Działalności podstawowej } \\
\text { operacyjnej }\end{array}$ & $\begin{array}{c}\text { Działalności pozostałej } \\
\text { operacyjnej }\end{array}$ & Działalności finansowej \\
\hline $\begin{array}{l}\text { - wynagrodzenie syndyka i jego } \\
\text { pracowników; } \\
\text { - ubezpieczenia społeczne i inne } \\
\text { świadczenia; } \\
\text { - koszty funkcjonowania biura syndyka; } \\
\text { - archiwizacja danych; } \\
\text { - koszty obwieszczeń prasowych; } \\
\text { - podatki i opłaty notarialne; } \\
\text { - } \text { wycena i zabezpieczenie majątku; } \\
\text { inne koszty upadłości działalności } \\
\text { podstawowej. }\end{array}$ & 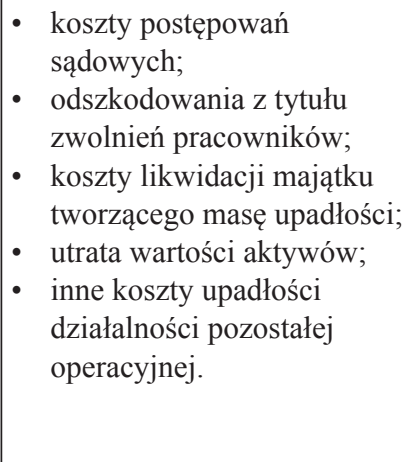 & $\begin{array}{ll}\text { - } & \text { odsetki } \\
\text { przeterminowane; } \\
\text { - } & \text { strata ze zbycia } \\
\text { inwestycji } \\
\text { tworzących masę } \\
\text { upadłóci; } \\
\text { - aktualizacja } \\
\text { wartości inwestycji } \\
\text { tworzących masę } \\
\text { upadłości; } \\
\text { - inne finansowe } \\
\text { koszty upadłości. }\end{array}$ \\
\hline
\end{tabular}

Źródło: opracowanie własne na podstawie [Sojak, Trojanek 2010, s. 101-103].

\section{Zakończenie}

Rola sprawozdań finansowych w przypadku jednostek w stanie upadłości jest szczególnie istotna. Do grupy odbiorców informacji pochodzących ze sprawozdań należą bowiem wszystkie strony postępowania upadłościowego. To w znacznej mierze na podstawie tych sprawozdań podejmowane są prawomocne decyzje sądu o przyszłości jednostki. Stanowią źródło informacji przydatnych do kontroli syndyka i ułatwiają weryfikację celowości, efektywności oraz skuteczności podjętych przez niego działań. Podstawą realizacji tych zadań jest jednak warunek, że sprawozdanie finansowe prezentuje wszystkie niezbędne do tego dane. Taką kluczową informację stanowią koszty postępowania upadłościowego.

W opracowaniu Autor przedstawia sposób ujawniania informacji o poniesionych i przewidywanych kosztach postępowania upadłościowego w sprawozdaniu finansowym. Jest to rozwiązanie przejrzyste i dostosowane do obowiązujących regulacji polskiego prawa bilansowego.

\section{Literatura}

Babiarz-Mikulska K., Czarpacka A., Morawska S., 2012, Ocena efektywności procedur upadłościowych wobec przedsiębiorców. Aspekty prawne, ekonomiczne i organizacyjne, Difin, Warszawa.

Boratyńska K., 2009, Koszty bankructwa przedsiębiorstwa na świecie i w Polsce-przegląd dotychczasowych badań, Zeszyty Naukowe SGGW w Warszawie, nr 78. 
Chłodnicka H., 2004, Koszty upadłości - klasyfikacja, pomiar i prezentacja, IV Ogólnopolskie Seminarium Doktorskie Rachunkowości i Finansów, WSFiR, Sopot.

Chłodnicka H., Zimon G., 2013, Wpływ kosztów upadłości na rentowność podmiotu gospodarczego, Prace Naukowe Uniwersytetu Ekonomicznego we Wrocławiu, nr 291.

Piotrowska K., 2014, Rachunek kosztów w warunkach upadłości likwidacyjnej, Prace Naukowe Uniwersytetu Ekonomicznego we Wrocławiu, nr 344.

Popławska J. (red.), 2004, Rachunkowość i podatki w postępowaniu upadłościowym, Stowarzyszenie Syndyków i Nadzorców Sądowych, Koszalin.

Sojak S., Trojanek M., 2010, Rachunek kosztów upadtości, [w:] Sojak S. (red.), Założyć firmę i nie zbankrutować - studia przypadków, Difin, Warszawa.

Świderska G.K., Więcław W. (red.), 2012, Sprawozdanie finansowe wedtug polskich i międzynarodowych standardów rachunkowości, Difin, Warszawa.

Tokarski A., 2012, Koszty upadłości w aspekcie rachunkowym, Zeszyty Naukowe Uniwersytetu Szczecińskiego, nr 737.

Ustawa z dnia 15 maja 2015 r. Prawo restrukturyzacyjne, Dz.U. z 2017, poz. 1508.

Ustawa z dnia 28 lutego 2003 r. Prawo upadłościowe, Dz.U. z 2017, poz. 2344.

Ustawa z dnia 28 lutego 2003 r. Prawo upadłościowe i naprawcze, Dz.U. z 2003, nr 60, poz. 535.

Ustawa z dnia 29 września 1994 r. o rachunkowości, Dz.U. z 2018, poz. 395. 